International Journal of Engineering \& Technology, $7(4.38)(2018) 1082-1085$
International Journal of Engineering \& Technology
SPC
Website: www.sciencepubco.com/index.php/IJET
Research paper

\title{
Creating the Appropriate Social and Economic Conditions for the Development of Agriculture: An Investigation into the Prospects for Engaging Young Specialists
}

\author{
Maira Shakibaevna Bauer, Zamira Tolegen ${ }^{1}$, Khalima Nugmankizi Mursalova1, Gaukhar Shakerbekovna \\ Baidalina $^{1}$, Lyailya Telgosinovna Bekbossynova ${ }^{1}$ \\ ${ }^{1}$ Seifullin Kazakh Agrotechnical University, Kazakhstan, Astana \\ *Corresponding author E-mail: maira_bauer@mail.ru
}

\begin{abstract}
This paper shares the findings from a study into issues related to attracting highly qualified specialists into the nation's agricultural sector.
\end{abstract}

Keywords: agriculture, staffing, employment.

\section{Introduction}

The unresolved issue of human resource potential has been one of the key factors in the backwardness of both the economic and social dimensions of the development of the agro-industrial complex, both in Kazakhstan and elsewhere around the world. To attract specialists into the sector, the Kazakh government has been implementing a number of relevant state programs [1-5]. In the period 2014-2016, the overall need for specialists and research personnel across the agro-industrial complex totaled 6,456 people. Based on data from local authorities, about $80 \%$ of entities within the agro-industrial complex are in need of specialists. Out of all college graduates who majored in an agriculture-related field, only 55\% had been employed in their field of study, $43 \%$ being those who attended college on a rural quote [2]. A major portion of young specialists placed to work in agricultural enterprises and organizations tend to return to the city once the mandatory job placement period is over, with the popularity of the agricultural sector still being low at the moment.

\section{Methods}

In conducting the research reported in this paper, the authors employed a set of theoretical and empirical methods, including induction and deduction, questionnaire-based surveys (surveys by questionnaire), individual and group interviews, observation, statistical data processing, and comparative analysis.

\section{Results and discussion}

The findings from the authors' sociological study indicate that decent pay is the highest priority for most young specialists. $18.8 \%$ of the respondents noted it was this major factor that could actually incline one to agree to work in a rural area. The authors traced positive dynamics for the indicator. In 2015, the figure was
$14.7 \%$, and in 2016 it was $17.3 \%$. Resolving the housing issue is another crucial condition for getting young specialists to work in a rural area pointed out by respondents, with $19.5 \%$ regarding it as one of the most significant issues $(12.1 \%$ noting the importance of providing one with free corporate housing, and $7.4 \%$ - with a concessionary loan for acquiring a dwelling). In 2015, the figure was $13.6 \%$ (7.5\% and $7.3 \%$, respectively), and in 2016 it was $13.8 \%$ ( $7.4 \%$ and $6.4 \%$, respectively). Quality roads connecting villages to cities and decent career prospects were recorded in 1 in 10 answers in 2017. The trend had persisted in the surveys conducted in 2015 and $2016-10.6 \%$ and $11.6 \%$, respectively. Agricultural specialists, likewise, thought of increases in the size of pay as being integral to improvements in the quality of life: $2015-20.6 \%, 2016-27.7 \%$, and $2017-10.3 \%$. Respondents in this group attached greater significance to communal goods, with over $40 \%$ desiring an improvement in this area in 2017, 29\% - in 2015 , and $29.1 \%$ - in 2016 .

There was a correlation between specialists' answers and students' wishes in a condition such as quality roads: $10.7 \%$ - in 2017 , and $4.3 \%$ and $4.2 \%$ - in 2015 and 2016, respectively. In 2017, providing children with quality preschool and school education accounted for a combined total of nearly $36 \%$ of the answers by specialists employed in a rural area. In 2015 and 2016, this figure was $16.1 \%$ and $13.9 \%$, respectively. This means these individuals are worried about the future generation.

It is worth noting that most students, across the overall three-year period, do not find it necessary to go back to where they used to live before for work. This may be a testimony to the need to consider the possibility of agricultural enterprises arranging for one to attend an educational institution in a special-purpose manner.

$33.2 \%$ of the executives surveyed agreed that raising pay for young specialists was one of the more efficient measures to take to help consolidate specialists in rural areas. In addition, $41.5 \%$ of them were of the view that providing a specialist with a concessionary loan to help them acquire a dwelling should serve as a significant aid in resolving their housing problem. 
Thus, it may be stated that there is a certain amount of correspondence between the views of agricultural executives and the expectations of graduates.

To search for consistent patterns across the specialists' answers and to establish an interrelationship between these indicators and the students' answers, the authors conducted an analysis of statistical information using the correlation analysis method (Table 1).

Table 1: Composite table of the coefficients for the correlation between the specialists' and students' answers

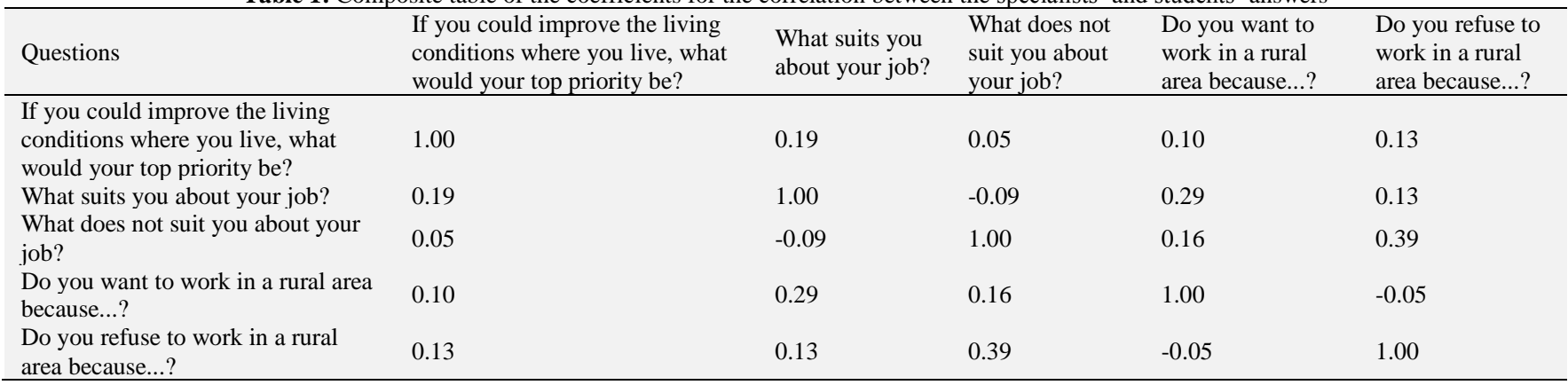

The question for specialists 'What suits you about your job?' had a high correlation with the question for students 'Do you want to work in a rural area because...?' -0.29 . This dependence would be classified as weak if the Chertok scale were used, but this level is quite acceptable in sociological research when it comes to analyzing and making decisions [6].

The correlation dependence is based on such criteria as ability to realize one's potential and build a successful career among students and prospects for career growth among specialists. The questions 'What suits you about your job?', employed in surveying agricultural specialists, and 'Do you refuse to work in a rural area because...?', asked of graduates, exhibited the greatest correlation -0.39 .

This level of correlation must have been the result of such conditions as intense pressure, tough working conditions with students and physically tough work with specialists, low pay with both of the respondent groups, irregular working hours and inconvenient work schedules, as well as most jobs being regarded by students as dead-end with little to no professional and career growth potential. It may be concluded that these criteria are having a certain amount of influence on graduates in making a decision as to whether or not to get a job in agriculture.

Overall, the findings from the authors' survey of agricultural executives exhibited a high level of understanding among them as to the issue of staffing in agriculture. Most of the respondents $(66.7 \%)$ noted declines in the level of provision of qualified workers and specialists for the sector, which substantiated the study's relevance and timeliness.

Going forward, the above key conditions could be taken into account in designing a set of appropriate measures aimed at attracting highly qualified specialists into agriculture.

The proposed measures were nominally divided into two large groups:

1. Group of democratic measures:

1.1 Boosting the prestige of agricultural professions.

Table 2 provides an assessment of the effect of the proposed measures aimed at attracting specialists into agriculture with respect to a set of requisite conditions established based on the findings from the authors' sociological study.

Table 2: Distribution of a Set of Relevant Conditions to Be Met in Alignment with the Proposed Measures (Democratic Measures) Aimed at Attracting Specialists into Agriculture

$\begin{array}{ccc}\text { Item } & \text { Measures aimed at attracting specialists into } \\ \text { agriculture } & \begin{array}{c}\text { Requisite conditions to be met, established through } \\ \text { surveying by questionnaire and interviewing relevant }\end{array}\end{array}$
target groups

1.1 Boosting the prestige of agricultural professions

2 Putting in place a sound benefits package for agricultural workers

3 Creating a high-speed transportation infrastructure that would connect rural areas to key cities

4 Ensuring accessible, sufficient, and quality preschool and high-school education for the children of specialists who will travel to rural areas for work

5 Ensuring adequate access to quality tap (potable) water

$6 \quad$ Setting up in rural areas various cultural, leisure, and sports institutions to ensure people's proper life-activity
Free corporate housing; concessionary loans for acquiring or building a place in the rural area; long-term concessionary loans for starting one's own business related to farming; long-term concessionary loans for starting one's own business not related to farming; sizable one-time cash assistance to help one organize one's household; quality healthcare

Proximity to the city; quality roads to the city; local roads with a hard surface

Quality preschool and high-school education

Continual access to quality potable water

Organized leisure: having in place the appropriate conditions for one to do sports and to take part in mass cultural activities and mingle with one's peers
Number of those willing to work in agriculture (based on the findings from the authors survey)

If the size of pay increased by 20 to $110 \%, 30 \%$ of the respondents would agree to work in agriculture, and if it did 4 times $-45 \%$; $60 \%$ would be satisfied with the size of their

pay if it went up

by additional $25-30 \%$

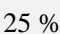

$5.6 \%$. 
7 Ensuring a proper level of operation of housing and utilities infrastructure

8 Developing an efficient employment program - which should involve setting up a set of enterprises with a non-agricultural focus - to meet the needs of immediate members of the family of attracted specialists

$9 \quad$ Providing rural areas with quality TV and Internet packages

10 Creating new large agricultural enterprises by reference to the region's special characteristics
Stable electricity supply; centralized heat supply; centralized cold and hot water supply; wastewater disposal

Opportunities for one's spouse or/and other family members to get a job related to one's field of study.

Access to the Internet and cable TV

$5.9 \%$.

Opportunities for one's spouse or/and other family members to get a job related to one's field of study.
$60 \%$
All of the target groups treat this criterion as the most important one in making a decision. If the size of pay increased by 20 to $110 \%, 30 \%$ of the respondents would agree to work in agriculture, and if it did 4 times $-45 \%$; $60 \%$ would be satisfied with the size of their pay if it went up by additional $25-30 \%$.

1.2 Putting in place a sound benefits package for agricultural workers. Providing specialists with corporate housing or with housing on an installment payment basis at the employer's expense, with the possibility of buying the place out in the future. Agricultural specialists will need quality medical care as well. 1.3 Resolving the transportation issue, as one of the key focus areas for narrowing the gap between urban and rural living conditions. This may require creating a high-speed transportation infrastructure that would connect rural areas to key cities. This would help ensure a convenient, safe, and steady linkage between rural and urban areas with a view to meeting the consumer and social/cultural needs of agricultural workers.

Based on the survey findings, this measure could boost the number of those willing to work in rural areas by $23 \%$. To the authors, a deciding factor is that young individuals who just separated from their parents spend less time on trips they will take for personal and business purposes.

1.4 Ensuring accessible, sufficient, and quality preschool and high-school education for the children of specialists who will travel to rural areas for work.

1.5 Ensuring adequate access to quality tap (potable) water. 3 to $10 \%$ of the respondents said they would work in agriculture if this condition were met.

1.6 Setting up in rural areas various cultural, leisure, and sports institutions to ensure people's proper life-activity, an issue that is increasingly gaining in relevance, as the growing level of these services in cities is causing the need to improve their level in rural areas as well [7].

1.7 Ensuring a proper level of operation of housing and utilities infrastructure, with $9.9 \%$ willing to work in agriculture if this condition is met.

1.8 Developing an efficient employment program - which should involve setting up a set of enterprises with a non-agricultural focus - to meet the needs of immediate members of the family of attracted specialists.

1.9 Providing rural areas with quality TV and Internet packages. Ensuring proper access to the Internet and cable TV could help attract into agriculture $5.9 \%$ of the surveyed graduates.

1.10 Setting up new large agricultural enterprises by reference to the region's special characteristics.

2. Group of administrative measures (proposed by the authors as recommendations):

2.1 To attract able-bodied highly qualified specialists, it may help to reinstitute the former system of having to work in one's field of study for 3-5 years after graduation, which is known to have been quite a success.

2.2 Providing subsidies to enterprises engaged in agricultural activity, which should include subsidizing $50-70 \%$ of expenditure associated with the payroll for young specialists [8].

2.3 Establishing work in agricultural production in rural areas as a mandatory condition for a successful public administration career in ministries and agencies, as well as enterprises within the agroindustrial complex. Meeting this condition should encourage young specialist to use their job in a rural area as a basis for moving up the career ladder [9].

2.4 Encouraging colleges and agricultural enterprises to enter into agreements for training students from rural schools (ideally, setting up specialized classes with a focus on agriculture) who have made up their mind to pursue a career in agriculture and work in a rural area at an agricultural enterprise.

\section{Conclusion}

In today's climate of globalization, amid the rapid development of new information technologies and stiffening of competition, the changes are also influencing the generation born during this time, whose representatives are distinguished by being independent, creative, predisposed to fast development, and easily adaptive to change. Today's agricultural sector needs talented young specialists who are capable of implementing new, cutting-edge technologies in production. This requires putting in place new research institutions and state-of-the-art educational programs [10].

Based on the study's materials, creating the appropriate social and economic conditions should help boost the number of specialists willing to work within the agricultural sector by an average of $19 \%$.

\section{References}

[1] Postanovlenie Pravitel'stva Respubliki Kazakhstan ot 18 fevralya 2009 goda No. 183 "Ob opredelenii razmerov predostavleniya mer sotsial'noi podderzhki spetsialistam $\mathrm{v}$ oblasti zdravookhraneniya, obrazovaniya, sotsial'nogo obespecheniya, kul'tury, sporta i agropromyshlennogo kompleksa, pribyvshim dlya raboty i prozhivaniya v sel'skie naselennye punkty". https://www.kazpravda.kz/dbases/view/4129 Revised February 2009. Accessed October 10, 2018.

[2] Postanovlenie Pravitel'stva Respubliki Kazakhstan ot 19 iyunya 2013 goda No. 636 "Ob utverzhdenii Dorozhnoi karty zanyatost 2020" (in Russian). http://adilet.zan.kz/rus/docs/P1300000636/links\#to Revised June 2013. Accessed October 10, 2018.

[3] Postanovlenie Pravitel'stva Respubliki Kazakhstan ot 18 fevralya 2013 goda No. 151 "Ob utverzhdenii Programmy po razvitiyu agropromyshlennogo kompleksa v Respublike Kazakhstan na 2013-2020 gody 'Agrobiznes-2020"' http://adilet.zan.kz/rus/docs/P1300000151/info Revised February 2013. Accessed October 10, 2018.

[4] Zakon Respubliki Kazakhstan ot 23 yanvarya 2001 goda No. 149-II "O zanyatosti naseleniya" http://www.adilet.gov.kz/ru/node/924 Revised December 2014. Accessed October 10, 2018.

[5] Ukaz Prezidenta Respubliki Kazakhstan ot 14 fevralya 2017 goda No. 420 "Ob utverzhdenii Gosudarstvennoi programmy razvitiya agropromyshlennogo kompleksa Respubliki Kazakhstan na 2017 2021 gody i vnesenii izmeneniya i dopolneniya v Ukaz Prezidenta Respubliki Kazakhstan ot 19 marta 2010 goda No. 957 “ Ob utverzhdenii Perechnya gosudarstvennykh program"”. (in Russian). http://www.government.kz/ru/zakonodatelnye-akty/ukazyprezidenta-respubliki-kazakhstan/1010953-ob-utverzhdeniigosudarstvennoj-programmy-razvitiya-agropromyshlennogokompleksa-respubliki-kazakhstan-na-2017-2021-gody-i-vneseniiizmeneniya-i-dopolneniya-v-ukaz-prezidenta-respublikikazakhstan-ot-19-marta-2010-goda-957-ob-utverzhdenii- 
perechnya-gosuda.html Revised August 2017. Accessed October $10,2018$.

[6] G. P. Artemov, Politicheskaya sotsiologiya: Uchebnoe posobie, Logos, Moscow, 2002. (in Russian).

[7] D. V. Zaichenko, Problema privlecheniya molodykh spetsialistov v sel'skuyu mestnost', 2016. (in Russian). http://www.scienceforum.ru/2016/1630/18643

[8] Postanovlenie Pravitel'stva RF ot 15 iyulya 2013 g. No. 598 “O federal'noi tselevoi programme "Ustoichivoe razvitie sel'skikh territorii na 2014-2017 gody i na period do 2020 goda" (in Russian). https://rg.ru/2013/07/29/selskie-site-dok.html Revised July 2013. Accessed October 10, 2018.

[9] A. R. Kuznetsova, Opyt rossiiskikh regionov po zakrepleniyu molodykh spetsialistov $\mathrm{v}$ agrarnom sektore ekonomiki [The experience of Russian regions in terms of consolidating young specialists within the agrarian sector of the economy], Mezhdunarodnyi Sel'skokhozyaistvennyi Zhurnal 1 (2008) 23-24. (in Russian).

[10] Otdel'nye problemy razvitiya sel'skogo khozyaistva v Kazakhstane. http://www.sarap.kz/index.php/ru/news/424/424.html Revised October 2014. Accessed October 10, 2018. 